\title{
A Study on Role of Teachers in Enhancing and Minimizing Factors Affecting Employability Skills
}

\author{
Gayatri Choukade* and Neelambika S. Ingalagi
}

Department of Education and Extension, Savitribai Phule Pune University, Pune

*Corresponding author: gayatri.choukade@gmail.com

Received: 09-03-2020 Revised: 16-06-2020

Accepted: 20-07-2020

\begin{abstract}
Enhancing the employability skills is considered as the important; the question that arises is whether India is actually creating enough jobs for its youth. For the 104.62 million fresh talents likely to enter India's labour market by 2022, the country would need to generate 8.1 million jobs annually. Failing to this objective will only add to the country's increasing unemployment rate that reached $6.1 \%$ in $2017-18$ fiscal, despite technological developments. Through this research paper authors want to explore the role of teachers with special reference to graduate students. This paper consist concept of employability, role of teachers in employability and factors affecting employability.
\end{abstract}

Keywords: Unemployment, jobs, youth, labour, higher education, talents

The higher education system in India has adopted many regulatory mechanisms from the legacy of higher education. The Indian education system ensured satisfactory functioning of the system with exceptional quantitative expansion, raising the standards of higher education could not be achieved. With 259 university level institutions, more than 10,750 colleges, 8 million students, and 4, 00,000 teachers, India has one of the world's largest higher education systems. However required quantity and quality of education is not achieved, they cover only 6 percent of the relevant age group, and 88 percent of student enrolments are in undergraduate education. The quality and of education provided to small quantity is vital to the success of the nation.

The country should make training a mandate among fresh talents and experienced professionals. With training workshops, the employable workforce even from the remote regions of the country will be able to learn and grasp the necessary practical skills that are required for developing the employability skills of students. The educational institutes should strengthen student life skills by providing them with training in entry-level areas.

\section{Problem statement}

This article concentrates on role of the educational institutions and teachers to fulfil the required expectations of the industry. There is increasing mismatch between design of conventional graduation education system and required design of education to enhance the employability needed for industries. There are numerous employment opportunities but employability is affected by both demand and supply side factors which are often outside of an individual control. It is imperative for the education institutes and industries to collaborate and prepare a concrete road map focused on launching newer training modules. Teachers and education institutes should have to deliver subject matter expertise to

How to cite this article: Choukade, G. and Ingalagi, N.S. (2020). A Study on Role of Teachers in Enhancing and Minimizing Factors Affecting Employability Skills. Educational Quest: An Int. J. Edu. Appl. Soc. Sci., 11(2): 69-74.

Source of Support: None; Conflict of Interest: None 
graduates to up skill and advance in economically and mentally fulfilling careers.

\section{Review literature}

The idea of employability skills and their emergence in the Higher Education Institutions (HEIs) through the analysis of the relevant literature. Study explores employability skills development in the Greek HEIs and the difficulties associated with it considering work-placements structure and current attitudes especially in the area of accounting education. (Procedia - Social and Behavioral Sciences, Asonitou, Sofia 2015).

Employer's perspectives on employability skills, employability skills gap and bridging the skills gap. The paper does not conclude in its own but facilitate more thinking on bridging the skill gap. The paper may also reveal few hypothesis's to researchers wish to work in this area (Higher Education and Employability - A Review, SSRN Electronic Journal, 2013).

Employability skill definitions, employer expectation and requirement differ according to different countries. Employers" needs and also the learners" skill enhancement capabilities should be taken into account in formulating future skills assessments. This study concludes that universities should identify skill sets that will best serve the future labor market and align programmes to meet those needs. (Susima Samudrika Weligamage-2009).

Guidance from ESECT (Harvey and Knight, 2003) acknowledges that policy and initiatives aimed at developing the employability role of higher education institutions has been met with some scepticism and some academic institutions have been required to make cultural changes to the way they operate which has resulted in universities engaging with the issue of employability to varying degrees (Harvey, Locke and Morey, 2002).

In classes that effectively teach employability skills, instructors assume the role of facilitators and coaches rather than lecturers and order givers, requiring students to take much of the responsibility for their own learning (Graham, Vitale, and Schenk 1991; Gregson 1992; Nagle 1987; Spill and Tracy 1982; and Stasz, et al. 1990, 1993).

\section{Role of the teacher}

Some of the skills are developed by repetitive execution and some of the skills are developed by seeing skilled persons, hence role of senior professors, lecturers and teaching associates makes the crucial role in developing the employability skills of their pupil. The current system for educational institutes and universities to be upgraded, the team building, integrity, entrepreneurship and passion for excellence to be developed. The scheduled programmes for teachers to give extensive exposure like vocational training and role plays followed by teacher assessment for employability skill.

The teacher role in developing employability skills for graduate students:

1. Interactive teaching: Various methods have been included in modern teacher training to Enhance the learning process of such skills as team-work, advanced communication, critical Thinking and problem-solving. One is interactive teaching, through which instructors facilitate exercises that provide opportunities for experience, practice, reinforcement, and reflection.

2. Using a coach in a workplace setting: through on-the-job training work experience, internships, and work-study programmes are all examples of teaching both technical and core skills in the workplace in a manner that achieves optimal authenticity.

3. Classroom simulates the workplace: This approach, which includes practice firms, Workshops, experiential learning and role play, provides an authentic context for teaching and practicing core work skills that gives the teacher control over the teaching agenda, while creating an environment that benefits from the improved job related skills of its students.

4. Teacher as a facilitator: It is very significant that students should sense that their teachers concern about them and thus teacher should become the best facilitator to the students in all the way. As a facilitator one has to direct and support students in learning for themselves as a self-explorer. Teachers should develop best learning environment 
which reflects the students' future in societal, intellectual occurrences. As a facilitator a teacher should bring a strong foundation for student's personal growth.

5. Teacher as a manager: Teacher's role as a manger is a very significant and imperative role in managing a class. A Teacher has to plan well in advance regarding handling the classes within the exact time, covering academics as well as interpersonal skills with various teaching techniques and skills which is obviously a path to practical approach. An experienced trainer based on their own experience can manage the timings.

6. Maximizing learners opportunities: This method of teaching as a process of creating and utilizing learning opportunities, a process in which teachers strike a balance between their role as mangers of teaching and act their role as mediators of learning activities skill.

7. Maximizing learners opportunities: This method of teaching as a process of creating and Utilizing learning opportunities, a process in which teachers strike a balance between their role as mangers of teaching and act their role as mediators of learning activities.

8. Problem-based learning: Using a problem based approach to learning is helpful in developing key skills, such as the application of number and information technology, as well as the specific key skill of problem face and solve. Students need to be exposed to problems that will enhance, but not undermine their confidence, so students can explore possible options and try out different techniques for resolving them.

9. Collaborative work: In developing the key skill of working with others, it is helpful to build in opportunities for students to work in pairs and small groups, so that students can actively participate to discuss their ideas, explain their reasoning and learn from each other. This way of working also provides scope for developing other key skills, particularly communication and problem solving.
According to Goodwin (2012) the role of teachers in following activities required builds the confidence in students to get in to industries:

$\square$ Help with Curriculum vitae, researching the jobs market and identifying skills gaps.

$\square$ They should be able have mock interviews with employers,

$\square$ Confidence building activities, involving running business or organization,

$\square$ Role and behavioural skills required for professional person in their job,

$\square$ Practicing presentation skills,

Personal support.

\section{Factors Affecting for employability skills}

According to an analysis of World Bank/DfID Knowledge and Skills for the Modern Economy Project by Andy Hargreaves, Boston College and Paul Shaw University of Victoria, In many countries, it is very challenging to attract qualified teachers for the teaching profession, the most expensive to educate and most difficult to retain in institutions, especially teachers those in high-demand areas, such as mathematics, science and technology. Teachers who remain in the system lack confidence and competence due to the erosion of their traditional subject-based authority as they face greater numbers of more challenging and changing students in a mass rather than elite system. Although there is remarkable convergence among interviewed stakeholders as to knowledge-society competencies that teachers should acquire and display in the classroom, teacher education programs still place most stress on content knowledge rather than knowledge of teaching and learning and of how to teach one's subject.

Teacher training is poorly equipped to address these problems. Teacher education reform therefore needs to move beyond listing the competencies that comprise and create quality learning, to articulating teacher education across a continuum of lifelong learning over time, and integrating it with school development, leadership development and strategies of systemic reform - with teachers working and learning together more in institutes that are stronger professional learning communities of quality and improvement. 
The Carnegie Foundation claims that personal qualities account for 85 percent of the factors contributing to job success and, according to the Harvard Bureau of Vocational Guidance, 66 percent of people fired from their jobs were fired because they failed to get along with people. The factors like Age, Gender, Basic Graduation, Spetialition, Family Background and income has no significant difference in the employability skills of students (Hansraj M. Patil ISSN 2455-2267; Vol.05, Issue 02 (2016).

\section{The factors affecting upgration of Indian employability skills are listed below}

1. Shortage of teachers: India is short of teachers and skilled teachers are rarer to come by. As of now, the country has roughly 8.5 million teachers and only 19,000 teacher training institutes. The focus on the right to education and quality of education is equally important and the Govt may look to improve education facilities. The Delhi government schools were recorded with 35,034 regular teachers. While the required strength was 64,096 , which is shortage of nearly $45 \%$ of teachers. ( Business insider India).

2. Lack of global pooling of scientist, researchers and teachers: Global pooling knowledge will ensure industry relevant skill training and building skills in technologies like Artificial Intelligence, Big Data, Virtual Reality, 3D printing and Robotics.

3. Lack of clarity in students in selfidentification of skills and road map for achieving the carrier: Educational institutes must address and champion to enable, empower and embolden students for inclusive growth and self-reliance. Developing new education policy and creating a road map to follow student's challenges. The main vision that guides largely on social relevance.

4. Lack of skills to match the changing needs of the digital world: "India's unemployment challenge is partly because of no accessibility of education, high dropout rates, labour market irregularities, a mismatch between the supply and demand of skills and the highly ambitions young generation," "Lack of skills was evident in new age digital technologies such as Artificial Intelligence, Machine Learning and Cloud Computing. Shortage skill sets can be fulfilled by the developing regulatory guidelines for various industries in order to create compulsory learning hours for employees.

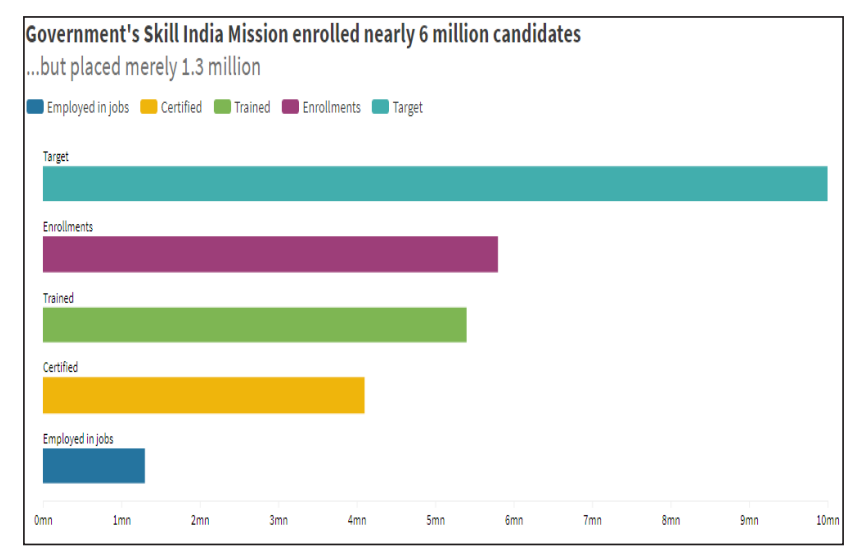

Fig. 1

5. Problem in developing and retaining the employability: Lack of qualities that needs to be improvement in teachers based on the training need identification. The good teacher's shall develop entrepreneurial qualities that are listed below:

* good collaborators,

* good communicators,

* reliable contributors,

* open-minded,

* non-judgemental,

* sensitive thinking - to avoid cultural conflicts,

* Flexible behaviour to suit different roles and situations, and

* Familiar in providing constructive support and feedback to others.

There are many aspects teachers and staff member as role models to the students:

* Share knowledge with others.

* Coordinate activities with others.

* Critically evaluate own teaching skills. 
* Provide specific, actionable feedback sensitively to others.

* Handle differences carefully

* Communicate respectfully.

6. System for evaluating the teachers for their continuous improvement: The Institutes shall establish the system for learning outcomes and assessment marking criteria to demonstrate clearly to trainers (teachers), so that they can train the trainees (students). The process of working in these aspects should be valued or rewarded on predefined frequency. The extent to which an individual's skills are developed is evidenced by their behaviour. The following list of behaviours can be used by the educational institutes for final assessment based on following skills:

* participates enthusiastically in reaches and discussion;

* expresses him/herself clearly and coherently;

* introduces new ideas;

* Constructive thinking;

* influences the direction and nature of the discussion;

* relieving a dominant interrupter to allow someone else to make a point;

Makes decisions collaboratively; and distinguishes clearly between the important and the insignificant. (Employability A Good Practice Guide, Centre for Learning and Development, 2013).

\section{Recommendation}

Some of the existing initiatives by the incumbent government are Industrial Training Institutes (ITIs) and Scheme for Higher Education Youth in Apprenticeship and Skills (SHREYAS) required for employability of the people through 'on the job work exposure'.

It is required to reshape the outdated learning pedagogies and curriculums at both school and college level to give student a broader and clearer view of where they stand and what they want to pursue in life. This would gradually encourage continuous learning and help foster a growth among youth across India. The multiple players including the government, industry, and academia collectively and constructively work along with government. All should work under a umbrella to prepare the youth for future jobs. Their combined efforts would rapidly help restructure our traditional educational system and make it more demand-led and skillbased, one of the most crucial requirements as of now.

Regular certification programs for our youth can also good solution to existing skill-gap and unemployment problem. These programs would allow individuals to test their knowledge, enhance their skills and help them understand relevant careers suitable for them. In due course, certifications will help companies seek and recruit the best industry talent for various job roles.

All such initiatives would help to learn, progress and develop new skills that will be prevalent for future jobs for young generation. Integrating technology in education to ensure creativity within the students, from the very growth stage. On successful implementation, the collaborative publicprivate efforts can influence the potential of youth and achieve large-scale success in the long run.

\section{CONCLUSION}

Modifications in the education system which will address the needs of the changing economy and take suitable measures at providing mandatory training and continuous improvement of teachers knowledge and skills with a view to have the youngsters gainfully employed. Understanding how businesses operate and getting clarity of the roadmap gives young people a better understanding of the world of work, enhancing their employability. Entrepreneurial training can provide teachers with basic corporate literacy. The skill based education requires systems of provision that are flexible, affordable and available. The new government initiatives like GIAN, IMPRINT and IND-SAT will definitely help to improvise the employability skills in India.

\section{REFERENCES}

Md Husain, Ch. Sravan Kumar, Saritha, G. 2017. International Journal of Engineering Technology Science and Research, 4(12).

Yoke, T.C. and Ngang, T.K. 2017. A study on soft skill development among final year diploma in business studies students. MOJEM: Malaysian Online Journal of Educational Management, 3(2): 32-50. 
Chap, AU Sharma and Harishchandra, P.Y. 2016. Employability skill Literature review in India. SN- '978-93-5249-048-6.

Jour, AU Nawaz, Nishad, AU - Reddy, P.Y. 2013. T1 - Role of Employability Skills in Management Education: A Review, vol. 3.

Goodwin, Vicki. 2012. "North West Graduate Employability Programme." York: Higher Education Academy. [Accessed 15 July 2014] Goodwin, Vicki (2012) “North West Graduate.
Employability Programme." York: Higher Education Academy. [Accessed 15 July 2014].

https://www.skillsyouneed.com/general/employability-skills. html

Resolution on skills for improved productivity,employment growth and development. $97^{\text {th }}$ Session the International Labour Conference, 2008. 